\title{
A Case of Liddle Syndrome: Correspondence
}

\author{
Zelal Ekinci
}

Received: 26 December 2013 / Accepted: 3 April 2014 / Published online: 15 May 2014

(C) Dr. K C Chaudhuri Foundation 2014

To the Editor: I read the article "A case of Liddle syndrome (LS)" with great interest which drew attention to the distinction between LS and Apparent Mineralocorticoid Excess (AME) with response to spironolactone [1]. However, there are some reports regarding the dosage and ineffectiveness of spironolactone on this subject [2-5]. I would like to share my experience to draw attention to the limitation of differential diagnosis with spironolactone on a hypertensive patient.

A 4.5-y-old boy presented with hypertensive encephalopathy. Medical history revealed polyuria, failure to thrive, low birth weight, consanguineous parents, intrauterine death of the first sibling, and lack of family history of hypertension. Physical examination was normal except for the presence of lethargy and high blood pressure (BP) $(185 / 135 \mathrm{~mm} \mathrm{Hg})$. Laboratory investigations revealed plasma sodium $146 \mathrm{mEq} / \mathrm{L}$, potassium $1.6 \mathrm{mEq} / \mathrm{L}$, chloride $97 \mathrm{mEq} / \mathrm{L}$, bicarbonate $31.3 \mathrm{mEq} / \mathrm{L}$, creatinine $0.6 \mathrm{mg} / \mathrm{dl}$; urine sodium $45 \mathrm{mEq} / \mathrm{L}$, potassium $15.2 \mathrm{mEq} / \mathrm{L}$, chloride $52 \mathrm{mEq} / \mathrm{L}$ and creatinine $13 \mathrm{mg} / \mathrm{dl}$. Supine plasma renin activity was $0.02 \mathrm{ng} / \mathrm{ml} / \mathrm{h}(0.05-2.5)$ and the aldosterone level was $15 \mathrm{pg} / \mathrm{ml}(20-180)$. Nitroprusside continuous IV infusion was initiated and titrated according to the BP; then spironolactone was initiated and the dosage was increased up to $12 \mathrm{mg} / \mathrm{kg} / \mathrm{d}$. In spite of the continued nitroprusside infusion, BP could not be controlled. Combined triamterine $(8 \mathrm{mg} / \mathrm{kg})$ and hydrochlorothiazide $[(4 \mathrm{mg} / \mathrm{kg})$ (TH; only combined form is available in Turkey)] was prescribed while spironolactone was withdrawn. BP control was achieved on the 8th day. Parents' consanguinity and the lack of family history of hypertension urged me to test spironolactone for the diagnosis of AME again. On the 11th day of hospitalization $12 \mathrm{mg} / \mathrm{kg} / \mathrm{d}$ spironolactone was

\section{Z. Ekinci $(\bowtie)$}

Division of Pediatric Nephrology, Department of Pediatrics, Kocaeli University Faculty of Medicine, 41380 Umuttepe, Kocaeli, Turkey

e-mail: zekinci@outlook.com reinstituted and $\mathrm{TH}$ was withdrawn. His $\mathrm{BP}$ rose up to $180 /$ $110 \mathrm{~mm} \mathrm{Hg}$ and $\mathrm{TH}$ was prescribed again. Evaluation of $\mathrm{ENaC} \alpha, \beta, \gamma$ and MR genes revealed no mutation. Recently, the urinary steroid metabolomics analysis revealed pathologic ratio of tetrahydrocortisol $+5 \alpha$-tetrahydrocortisol/ tetrahydrocortisone $(7.39$; normal: $<2.5)$ and definitive diagnosis was established as AME. He is now on $\mathrm{TH}$ and spironolactone. Thus, spironolactone test is not a safe and sensitive method for differential diagnosis of AME and LS.

Acknowledgments The author would like to thank Hae Ill Cheong, Department of Pediatrics, Seoul National University Children's Hospital, Research Coordination Center for Rare Diseases, Seoul National University Hospital, Kidney Research Institute, Medical Research Center, Seoul National University College of Medicine, Seoul, Korea; for the genetic evaluation and Stefan A. Wudy, Steroid Research \& Mass Spectometry Unit, Center of Child and Adolescent Medicine, Justus Liebig University, Feulgenstrasse 12, 35392 Giessen, Germany; for the urinary steroid metabolomics analysis.

\section{Conflict of Interest None.}

Source of Funding None.

\section{References}

1. Sinha R, Salphale I, Agarwal I. A case of Liddle syndrome. Indian J Pediatr. 2013;80:878-80.

2. New MI, Levine LS, Biglieri EG, Pareira J, Ulick S. Evidence for an unidentified steroid in a child with apparent mineralocorticoid hypertension. J Clin Endocrinol Metab. 1977;44:924-33.

3. Oberfield SE, Levine LS, Carey RM, Greig F, Ulick S, New MI. Metabolic and blood pressure responses to hydrocortisone in the syndrome of apparent mineralocorticoid excess. J Clin Endocrinol Metab. 1983;56:332-9.

4. Fiselier TJ, Otten BJ, Monnens LA, Honour JW, van Munster PJ. Low-renin, low-aldosterone hypertension and abnormal cortisol metabolism in a 19-month-old child. Horm Res. 1982;16:107-14.

5. Monnens L, Levtchenko E. Distinction between Liddle syndrome and apparent mineralocorticoid excess. Pediatr Nephrol. 2004;19:118-9. 